DOI 10.18551/rjoas.2019-10.16

\title{
COMMUNITY EMPOWERMENT BY STRENGTHENING VILLAGE OWNED ENTERPRISES SRIMARTANI MAKMUR IN PIYUNGAN
}

\author{
Ghofar Abdul ${ }^{\star}$, Kismantoroadji Teguh, Harilaksana Dwi \\ University of National Development "Veteran" Yogyakarta, Yogyakarta, Indonesia \\ *E-mail: abdulghofar@upnyk.ac.id
}

\begin{abstract}
The issue of this research is related to the ways on how to improve the community empowerment through the empowerment process and the actors' ability. The aim of the research is to analyze the influence of the actors' ability on their empowerment level through the process of empowerment. The design of this research is descriptive and it is expected to be able to explain the phenomena of the community empowerment and to direct numerous government's policies related to the attitude aspect of the empowerment actors. The data used are primary data, gathered by using survey method through questionnaires. The analysis technique is Path Analysis. The research result shows that there is a significant influence of the variable of empowerment actor to the community empowerment level through the empowerment process as the mediator variable. The implementation of this research is that the community empowerment level needs a process and it is supported by the improvement of the actors' ability. It is expected that from this research result, the local government, especially Piyungan village can support the implementation of the community empowerment process so that it can increase the community income by strengthening the village owned enterprises Srimartani.
\end{abstract}

\section{KEY WORDS}

Actors, process, community empowerment level, village owned enterprises.

Developing the village life can be reached through the community empowerment process with the aim at increasing productivity and the various existing businesses, fulfilling the facilities and infrastructure to support the economic increase in the village, building and strengthening the institutions that support the production and marketing chain, and optimizing the human resources as the basis of village economic growth.

According to the United Nations Development Program, community welfare is measured with the Human Development Index, which serves as the indicator in development sector, namely education, health, and economy.

The mission of the Midterm Development Plan of Bantul regency in 2016-2021 is to realize the community welfare and it focuses on the acceleration of the community economic development and the poverty alienation, with the development target to generate the qualified and creative industries with the indicator of creative industry scope of $35 \%$ based on the target (Midterm Development Plan of Bantul, 2017)

The final goal of this community empowerment process is to create independent community so that they can improve their life quality and can optimize the resources that they have (Kesi Widjajanti, 2011). Besides, according to Kussujaniatun and Kismantoroadjie (2017), the social interaction has significant influence on the community empowerment, and this will be reached by the great cooperation between the craftsmen and the local government that needs to be maintained, the interaction with the partners in producing the products, the interaction with the supplier about the raw material availability, the interaction with the brokers/agents in marketing, and the interaction with the banking partners about the capital given.

Kismantoroadjie and Kussujaniatun (2017) suggest that the potentials of a region need to be managed well. Besides making the region to be known more by the society, they will also get some profits, and this is surely supported by the better attitude of the craftsmen in doing the businesses. 
The finding of the research conducted by Kesi Widjajanti shows two patterns in improving the level of empowerment of the community (Kesi Widjajanti, 2011).

The research interest is about the significance of the variable of empowerment actors and empowerment process in improving the level of the community empowerment. This is one of the ways to improve the performance of the Micro, Small, and Medium-sized Enterprises, which is expected to strengthen the village owned enterprises Srimartani Makmur in Piyungan.

The existing problem right now is that there are not many people in the community that really utilize the available potential in their region. Most of the village owned enterprises are not performing well yet. It is proven by the fact that out of 26 enterprises, there is only one village owned enterprise that has the "advanced" predicate, which is Panggungharjo village owned enterprise. Meanwhile, village owned enterprise Srimartani in Piyungan still starts to grow, so that it is interesting to be researched. The community empowerment needs to be done. They need to realize what potentials that they have in their neighborhood that can be utilized. Therefore, this needs to be supported by developing the actors' ability and the empowerment process so that it can increase the empowerment level of the Micro, Small, and Medium-sized Enterprises so that eventually the strengthening of the village owned enterprise can be realized. Based on the problem stated above, then it is crucial to conduct the community empowerment program to increase the community income.

\section{MATERIALS AND METHODS OF RESEARCH}

Empowerment is a process and an effort to obtain or to give the power, strength or ability to the weak individuals and society so that they can identify, analyze, and determine the needs and the potentials as well as the problems that they face and also choose the best alternatives for the solutions by optimizing the resources and the potentials that they have independently (Hartati Anis, 2017).

Community empowerment level deals with the level of power, strength, or ability that the society possesses to identify the potentials and the problems as well as to determine the alternatives for the solutions independently. The indicators of the community empowerment level are: (a) ability in decision making, (b) independency and (c) ability to utilize the business for the future.

Empowerment actors' ability is the abilities of the empowerment actors that are expected to be able to empower the community. The indicators of the actors' ability are: (a) knowledge / cognitive, (b) affective, and (c) skills/psychomotor. Empowerment process is a cycle or a process that involves the society to cooperate in formal and informal groups to review a problem, to plan, to conduct, and to evaluate the program that has been planned together.

Empowerment process is measured by (a) quality and quantity of the community involvement starting from the review activity or problem analysis, (b) program planning, (c) program implementation, and (d) continuous involvement in evaluation process (Kesi Widjajanti, 2011).

The previous research with the variables of physical capital, human capital, social capital, and actors' ability in empowerment shows positive influence to the empowerment level of the society (Hartati Anis, 2017). Meanwhile, another research result shows that involving women in improving the women empowerment can support the increase of the income in the families (Kussujaniatun, 2014).

Starting from the Constitution number 6 of year 2014 and then the Village Ministry regulation of year 2015 about administration, establishment and management of the village owned enterprise. Then, there is a need to conduct the strengthening of the village owned enterprise with the mission to build the independency of the village and provide the service to the country.

Government Regulation number 43 year 2014 that is changed into Government Regulation number 47 year 2015 states that nowadays villages has the rights to manage the resources and the directions of the villages development. This gives a hope for the village 
community to change. Therefore the dynamics of the village life really depends on the participation of the community in supporting the efforts to reach an agreement of how to manage the village, and to build and develop the values of social, cultural, and economic as well as knowledge.

The research problem is related to the variables of the empowerment actors' ability and the process of the empowerment that influence the level of empowerment of the Micro, Small, and Medium-sized Enterprises. In addition this research also formulates the empowerment model that is suitable for the conditions of the locations in Piyungan, Bantul. The purpose of this research is to analyze the direct influence of the empowerment actors' ability on the empowerment level of the Micro, Small, and Medium-sized Enterprises through the empowerment process as the mediator variable. Eventually, it is expected that from this research result and with the cooperation with the village-owned enterprises and the local government in Bantul, the community empowerment can be improved.

The research design is descriptive and it is expected to be able to give the explanation about the model of the empowerment actors and to direct numerous government policies in improving empowerment, especially for the Micro, Small, and Medium-sized Enterprises. The research sample is 75 Micro, Small, and Medium-sized Enterprises with the active participation in the coverage of village-owned enterprises Srimartani Makmur in Piyungan, Bantul. The data gathered are primary data, obtained using survey method through questionnaires. The analysis technique in this research is Path Analysis.

Empowerment actors' ability is the abilities of the actors of the empowerment that are expected to be able to empower the community. The indicators of the empowerment actors' ability are: (a) knowledge/cognitive, (b) affective attitude, and (c) psychomotor skills. Empowerment Process is a cycle or a process that involves the community to cooperate in formal and informal groups to review the problem, to plan, to conduct, and to evaluate the program that has been planned together. Empowerment process is measured by (a) quality and quantity of the community involvement starting from the review activity or the problem analysis, (b) program planning, (c) program implementation, and (d) involvement in continuous evaluation. Community Empowerment Level is the power, strength, and ability that the community possess to identify the potentials and problems and to determine the solution alternatives independently. The indicators of the community empowerment level are (a) ability in decision making, (b) independency, and (c) ability to take advantage of the business for the future (Kesi Widjajanti, 2011)

\section{RESULTS AND DISCUSSION}

The research result shows that the village-owned enterprises Srimartani Makmur in Piyungan are developing village-owned enterprises in trades, agriculture, clean water management and waste management fields. The agriculture and trades fields get more attention than the other fields. Meanwhile, clean water and waste management still do not have proper attention and management.

The ability of the empowerment actors (MSME) can influence the empowerment process for $0.562(56.2 \%)$ since they can make use of the resources that they have to add leverage and competitiveness in improving the economic and the welfare of the Micro, Small, and Medium-sized Enterprises.

Empowerment process can influence the empowerment of Micro, Small, and Mediumsized Enterprises for 0.436 (43.6\%) since based on the learning process that they had, it can add the experience and improve the ability of Micro, Small, and Medium-sized Enterprises in developing their businesses.

The ability of the empowerment actors in Micro, Small, and Medium-sized Enterprises can directly influence the community empowerment level for $0.299(29.9 \%)$. It means that with the improvement of the resources of Micro, Small, and Medium-sized Enterprises, it surely will bring positive influence in families and neighborhoods.

It can be seen that the empowerment process has more influence to the empowerment level of Micro, Small, and Medium-sized Enterprises. This is due to the fact that the 
empowerment actors (MSME) will not act without trigger process. Even if they act, only few of them act continuously. However, with the empowerment process, the clear plans and the target will be established and it will lead to succeed for the motivators, process, and the actors of empowerment.

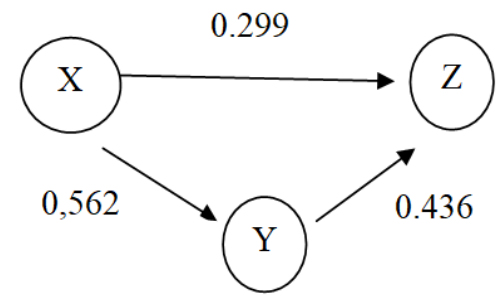

Notes: $X$ - Actors' ability (MSME); $Y$ - Empowerment process; $Z$ - Community empowerment level (MSME).

Direct influence: $X \longrightarrow Z=0.299$.

Indirect influence: $0.562 \times 0.436=0.245$.

Since the indirect influence $(0.245)$ is less than the direct influence $(0.299)$ then the empowerment process does not have active role as mediator variable.

\section{CONCLUSION}

The variable of the empowerment actors' ability has direct influence to the community empowerment level. The variable of the empowerment actors' ability has direct influence to the empowerment process. The variable of empowerment process has direct influence to the community empowerment. The variable of empowerment actors' ability has indirect influence to the community empowerment level through the variable of empowerment process as the mediator variable. Since the indirect influence is less than the direct influence, then it is proven that the empowerment process does not have active role as mediator variable in influencing the community empowerment, especially MSME in village-owned enterprises in Srimartani Makmur, Piyungan.

\section{REFERENCES}

1. Kismantoroadji, Teguh. 2008. Bantuan Benih Kedelai dan Dampaknya Terhadap Kelembagaan Petani di Gunungkidul DIY (Soy Seed Prosiding Seminar 2008. (Soy Seed Donation and Its Effects to the Framers' Institutional in Gunung Kidul).

2. Kismantoroadji, Teguh. 2008 Problematika Ketersediaan dan Agribisnis Perbenihan Padi di Kabuapten Bantul Prosiding Seminar 2008 UPN "Veteran" Yk V. (Availability Problems and Agribusiness of Rice Seeds in Bantul Regency).

3. Kussujaniatun, Sri, dan Kismantoroaji,Teguh. 2017. Community Empowerment In Teak Root Potential Area. 7th International Conference on Biotechnology and Environmental Management (ICBEM 2017).

4. Kussujaniatun,Sri.,Kismantoroadji, Pengaruh Peningkatan Sosial dan Ekonomi terhadap Perilaku Kewirausahaan, International Conference on Technology Engineering and Social Science, HASE, Nabu Research Academy, 2017. (The Influence of SocioEconomic Improvement on Entrepreneurship Behavior).

5. Kussujaniatun, Sri. 2009. Analisis Strategi membangun Loyalitas konsumen melalui Differensiasi produk. (Survai pada pengguna sepeda motor "Yamaha Mio" di Kab Sleman) Seminar Nasional V Call for Paper UTY. ISBN: 978-979-1334-25-9, 18 juli 2009. (Strategy Analysis in Building Consumers' Loyalty through Product Differentiation - A Survey on Yamaha Mio riders in Sleman).

6. Kussujaniatun, Sri. 2014. Pengentasan Kemiskinan: Motivasi dan Budaya perempuan dalam mekanisme Pemberdayaan Perempuan berbasis Pendekatan potensi di Kecamatan Berbah Sleman. Seminar Nasional, Program Studi Manajemen Fakultas Ekonomi UPN "Veteran" Jogjakarta. Proceeding SINAU 3, 2014. (Poverty Alleviation: 
Women Motivation and Culture in the Mechanism of Potential-Based Women Empowerment in Berbah, Sleman).

7. Penyusunan Model Pembangunan Ketahanan Pangan di Provinsi Daerah Istimewa Yogyakarta Dr. Ir. Siti Syamsiar, MP. Dr. Ir. Budiarto, MP Antik Suprihanti, SP., M.Si. Dana APBD DIY 20 juta (Establishing the Development Model of Food Resistance in Yogyakarta, Regional Revenue and Expenditure Budget in Yogya of 20 million).

8. Peraturan Pemerintah Republik Indonesia Nomor 43 Tahun 2014 Tentang Peraturan Pelaksanaan Undang-Undang Tentang Desa.Undang-Undang No. 19 Tahun 2003 tentang Badan Usaha Milik Negara. (Government Regulation of Republic of Indonesia Number 43 Year 2014 about the Stipulations of the Regulations of the Constitutions Number 19 Year 2003 about State-Owned Enterprises).

9. Rencana Pembangunan Jangka Menengah Daerah (RPJMD) (Regional Mid-term Development Plan) Kabupaten Bantul 2016-2021.

10. Widjajanti, Kesi. 2011. Model Pemberdayaan Masyarakat (Community Empowerment Model). Semarang. Jurnal Ekonomi Pembangunan (Development Economic Journal). Volume 12, Nomor 1, Juni 2011, hlm.15-27. 